\title{
The Determinants of Islamic Banks' Stock Prices: Evidence from the GCC Countries
}

\author{
Muhammad Muhajir Aminy ${ }^{1)}$, Ahmad Sauqi ${ }^{2)}$ \\ ${ }^{1}$ Faculty of Economics and Islamic Business, UIN Mataram \\ ${ }^{2}$ Faculty of Agriculture, Universitas Mataram \\ *Email correspondence: azeer.elkhawarizm@uinmataram.ac.id
}

\begin{abstract}
Islamic banks' stock is a new interesting material to be discussed among Islamic economics scholars. The majority of Islamic banks' stocks presents in the middle-east countries, especially those which are joining as the Gulf Cooperation Council (GCC) countries. Samples in this study were 10 Islamic banks in the Gulf Cooperation Council (GCC) countries with secondary data from their financial report. A panel data regression analysis was employed to seek the influence of all observed variables (ROA, ROE, and ICSR (zakat)) as the determinant factors toward Islamic banks'stock prices. The study found that all the independent variables simultaneously have an impact on Islamic banks' stock prices in that area. The study also found that the variable of ROA has a negative significant impact, the variable of ROE has a positive significant impact, and ICSR (zakat) has an insignificant impact on Islamic banks' stock prices in the GCC countries. This study suggested all Islamic banks globally to consider investors' sentiment on Islamic banks' financial condition before entering the Islamic capital market.
\end{abstract}

Keywords : Islamic banks' stock prices, ROA, ROE, ICSR, investment

Citation Suggestions: Aminy, M. M., \& Sauqi, A. (2020). The Determinants of Islamic Banks' Stock Prices:

Evidence from the GCC Countries. Jurnal Ilmiah Ekonomi Islam, 6(03), 535-542. doi:http://dx.doi.org/10.29040/jiei.v6i3.1284

DOI: http://dx.doi.org/10.29040/jiei.v6i3.1284

\section{INTRODUCTION}

Islamic banking has been widely spread over the world with its Islamic financial products. The differences between Islamic banks' products have been analysed by most Muslim academicians and scholars, particularly those who work with researches focusing on Islamic economics topics, specifically Islamic banks as Islamic financial institutions.

Islamic banks' assets have reached more than $16 \%$ per annum globally throughout the world between 2010 and 2014. In 2010, it had achieved USD 490 billion, and still increasing to the amount of USD 882 billion for the year of 2014. The most significant contributing countries for this increase come from an area namely the Gulf Cooperation Council (GCC) countries in the middle-east region, followed by Islamic banks in ASEAN countries (including Indonesia and Malaysia) as the second contributing countries, Turkey, and South Asia.
Figure 1. Total of Global Islamic Banks' Assets (In billions of USD)

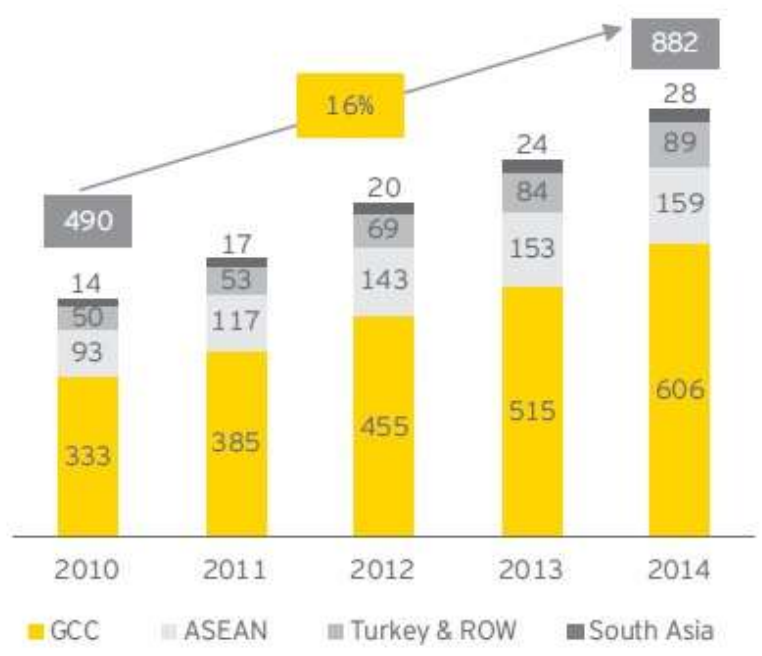

source: World Islamic Banking Competitiveness 2016

The GCC countries are consisted of the wealthiest countries in the middle-east region and are joining in a regional political organisation around the 


\section{Jurnal Ilmiah Ekonomi Islam, 6(03), 2020, 536}

Persian Gulf. This organisation is established in the year of 1981 in Abu Dhabi with joining countries are Bahrain, Kuwait, Oman, Qatar, Saudi Arabia, and United Arab Emirates (Sikimic, 2017).

The number of Islamic banks issuing their stock publicly inside the capital market is limited globally. In Indonesia, there are few Islamic banks which confidently launched their stock to be public investment instrument inside the Islamic capital market and will be traded by Islamic capital market's investors in both, primary and secondary market. At the same time, according to the data collected from www.marketstoday.net, the GCC countries has approximately 19 Islamic banks which have launched their common stocks to collect investment fund in the capital market. These Islamic banks are fully operating as full-fledged Islamic banks.

Stock return is a type of profit gained by investors in both, general and Islamic capital market, as reward on their stock investment which consisted of corporate dividend and capital gain (Suharli, 2008). The stock return also can be defined as a rate of return from an investment (Hartono, 2008). The stock return has a strong correlation with the stock prices because the method used in measuring stock return is based on stock prices within one specific period. High stock return indicated increasing the company's stock prices inside the capital market. It can be assumed that the stock is a prospective one to be an alternative investment instrument by investors and vice versa when the stock reached the lowest prices in the market. By understanding one specific company's stock prices, an investor can calculate the return (Tandelilin, 2001).

Profitability level reported on the company's financial statement showed the performance of the company. It contributed and can drive stock prices volatility inside the capital market. Profitability ratios, like Return on Asset (ROA) and Return on Equity (ROE), are often used by investors to make an investment decision on a stock's company. The basic concept of signalling theory stated that company management has accurate information regarding internal values and are not exposed to the external of the company (Pinches, 1996). Company's information, particularly its financial reporting, would help ordinary investors to make investment decision inside the market. Positive information regarding the company's current condition is a positive signal for investors, and vice versa (Jogiyanto, 2000). A study regarding the effect of profitability ratio, namely Return on Asset (ROA), on banks' stock prices in Yordania showed a significant positive effect of the observed variable towards the stock prices volatility (Al Nimer et al., 2013). In another research, the significant positive impact of profitability ratio, namely Return on Equity (ROE), can be found in a study with several companies in Saudi Arabia listed inside the capital market as the research samples (Barakat, 2014).

Islamic Corporate Social Responsibility (ICSR) is a form of CSR constructed based on the value of the Holy Qur'an and the Sunnah dan continuing to develop in Islamic economics knowledge (Reskino, 2016). This CSR type specifically refers to Islamic charity by company, such as zakat, infaq, and sadaqah. ICSR disclosure reported on the financial statement can attract investors' attention. Hence, the stock prices can be affected by this variable. Legitimation theory stated that disclosing Corporate Social Responsibility (CSR) to the public can effectively obtain communities' legitimation (Hadi, 2011). This effort was made to maximise a company's long-term financial performance. It also would make an excellent reputation for the company in the eyes of its investors. A study showed that CSR disclosure reported on financial statement has a significant positive influence on the financial performance of several companies in the Gulf Cooperation Council (GCC) countries (Dixon et al., 2016). Better financial performance would lead to a higher reputation of the company seen from investors' perspective.

The purpose of this study is to analyse the impact of profitability ratios, namely ROA and ROE, and ICSR disclosure on the volatility of stock prices in the Islamic capital market. In this research, the author proposes ICSR as a novelty, specifically the company's zakat disclosure, to be an independent variable with Islamic banks' stock prices as the dependent variable.

\section{THEORETICAL BACKGROUND AND HYPOTHESES DEVELOPMENT}

According to Fatwa DSN-MUI No. 40/DSNMUI/X/2003, Islamic stock is proof of owning a company that meet criteria and do not contradict with Islamic rules. This stock does not include preferred stock with an exclusive right for its holders. Amongst the criteria for a company to be listed as Islamic stock's issuers are: 1) company's activities, products, 
contract of agreement, and how to manage the company are not allowed to contradict with Islamic orders, 2) un-Islamic financial institutions involving the rate of interest in their daily activities do not include as Islamic stock's issuers, 3) all companies, including trading and distributing companies, related to un-Islamic products and contradicting with Islamic rules are prohibited from being Islamic stock's issuers, and 4) companies with debt level to un-Islamic financial institution greater than their capital are unlisted as Islamic stock's issuing companies.

Stock price commonly becomes the primary attention of investors in the capital market. It is the first spot to be noticed when investors enter the capital market through their brokerage's trading application. The stock price can be defined as a price created inside capital market based on supply and demand mechanism by investors, stocks' buyers and sellers (Jogiyanto, 2000). Stock prices are divided into several categories: 1) nominal price, 2) initial price, 3 ) market price, 4) opening price, 5) closing price, 6) highest price, 7) lowest price, and 8) averaging price (Widiatmojo, 2001). The volatility of the stock price is a common event created based on high trading activities within the market.

Profitability shows the financial performance of a company. Profitability is explained as a company's ability to obtain profit from selling product and with the number of assets and owned capital. Profitability level of a company may affect investors' perspectives toward the company itself. Profitability level also can be an instrument to evaluate company performance to manage their funds within one specific period (Djarwanto, 1997). Return on Asset (ROA) as a profitability indicator is estimated by dividing Earning Before Income Taxes (EBIT) with Total Assets. Return on Equity (ROE) as another profitability indicator is calculated by dividing Earning Before Income Taxes (EBIT) with Total Equity. A high value of ROA and ROE is preferable for investors because this is a positive signal that the dividend paid to them periodically by the stocks' issuers will increase (Suhardjono, 2002).

Islamic Corporate Social Responsibility (ICSR) is similar to general CSR, as implemented widely in most companies over the world. CSR concept itself is a form of responsibility from companies to help and create a better economic condition to improve the quality of societies' lives (Yusuf \& Bahari, 2015). The main difference between ICSR and general ICSR is values created inside. ICSR brings Islamic values into the frame and founded based on Islamic teachings recorded on the Holy Qur'an and As-Sunnah. Meanwhile, the concept of general CSR is based on western perspective without considering the Islamic values and principles (Yusuf \& Bahari, 2015). ICSR in Islam could be implemented into zakat form, which is compulsory for all Muslims. This Islamic charity is one of five pillars and obligation in Islam. Zakat can be defined as a small number of funds given to the beneficiary of zakat (mustahik) by Muslims following Islamic rules set by God (Mahmudi, 2009).

Based on several explanations aforementioned, the author proposes a research model which can be designed as follows:

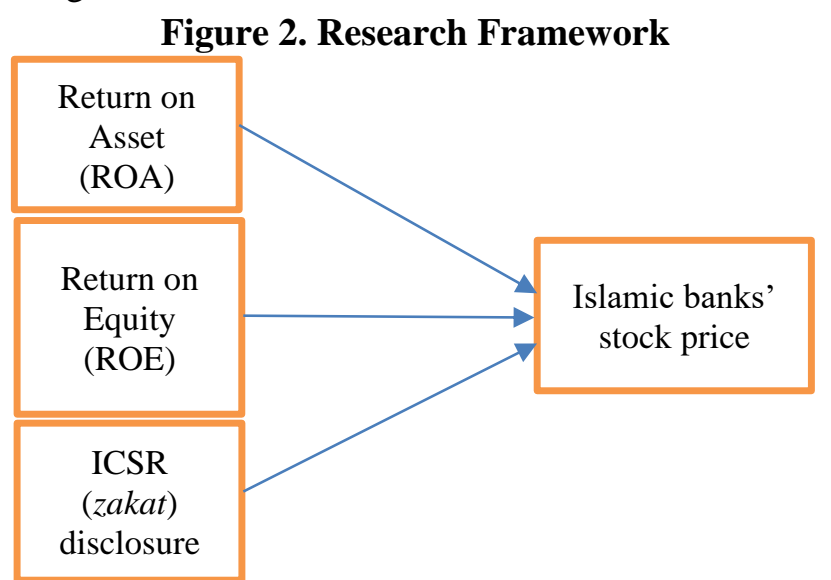

The Impact of Profitability Ratios, namely ROA and ROE, on Islamic Banks' Stock Price in the GCC Countries

The basic concept of signalling theory stated that company management has accurate information regarding internal values and are not exposed to the external of the company (Pinches, 1996). Company's information, particularly its financial reporting, would help ordinary investors to make investment decision inside the market. Positive information regarding the company's current condition is a positive signal for investors, and vice versa (Jogiyanto, 2000). A study regarding the effect of profitability ratio, namely Return on Asset (ROA), on banks' stock price in Yordania showed a significant positive effect of the studied variable towards the move of the stock price (Al Nimer et al., 2013). In another research, the significant positive impact of profitability ratio, namely Return on Equity (ROE), can be found in a study with several companies in Saudi Arabia listed inside the capital market as the research samples (Barakat, 2014). 
H1: ROA has a positive significant impact on Islamic banks' stock price

H2: ROE has a positive significant impact on Islamic banks' stock price

The Impact of ICSR (zakat) Disclosure on Islamic Banks' Stock Price in the GCC Countries

ICSR disclosure reported on the financial statement can attract investors' attention. Hence, the stock price can be affected by this variable. Legitimation theory stated that disclosing Corporate Social Responsibility (CSR) to the public can effectively obtain communities' legitimation (Hadi, 2011). This effort was made to maximise a company's long-term financial performance. It also would make an excellent reputation for the company in the eyes of its investors. A study showed that CSR disclosure reported on financial statement has a significant positive influence on the financial performance of several companies in the Gulf Cooperation Council (GCC) countries (Dixon et al., 2016). Better financial performance would lead to a higher reputation of the company seen from investors' perspective.

H3: ICSR (zakat) disclosure has a positive significant impact on Islamic banks' stock price

\section{RESEARCH METHOD}

This research used a quantitative approach to analyse collected data. Secondary data in this study are obtained between 2011 to 2015 . The data sources are financial reporting from all observed Islamic banks in the GCC countries.

This study employed a panel data regression analysis to seek the influence of all observed variables (ROA, ROE, and ICSR (zakat)) toward Islamic banks' stock prices. The author used StataSE 12.0 as a quantitative analysis tool in this research. The research samples are 10 Islamic banks in the GCC countries which have fulfilled the criteria as follow: 1) Launched their common stocks to public for trading need among investors, 2) All information regarding financial statement is available on the website, 2) Information of the amount of zakat spending is disclosed inside a financial statement, 3) No negative value for required financial data.

According to these criteria, samples that will be used in this study are:1) Al Rajhi Bank, 2) Alinma Bank, 3) Bank Al Bilad, 4) Bank Al Jazira, 5) Abu Dhabi Islamic Bank, 6) Sharjah Islamic Bank, 7) Dubai Islamic Bank, 8) Qatar Islamic Bank, 9) Qatar International Islamic Bank, and 10) Boubyan Bank. The equation model for this study using panel data regression analysis is as follows:

$$
S P_{i t}=\alpha+R O A_{i t}+R O E_{i t}+I C S R z a k a t_{i t}+\varepsilon_{i t}
$$

$\begin{array}{ll}\text { SP } & \text { : Islamic banks' stock prices } \\ \text { A } & \text { : Constanta } \\ \text { ROA } & : \text { Return on Asset } \\ \text { ROE } & : \text { Return on Equity } \\ \text { ICSRzakat } & : \text { ICSR in the form of total zakat paid by } \\ & \text { Islamic banks }\end{array}$

Return on Asset (ROA) is calculated by dividing total of Islamic banks' net income with total asset. Return on Equity (ROE) is a calculation of total of Islamic banks' net income divided with total equity. ICSR (zakat spending) is the amount of zakat paid by the observed Islamic banks in the GCC countries.

\section{RESULT AND DISCUSSION}

\subsection{Chow Test}

Chow test is the best testing method in panel data regression analysis which compares between Pooled Least Square (PLS) and Fixed Effect Model (FEM) by interpreting the result of FEM.

Table 1. Fixed Effect Model (FEM) Result

\begin{tabular}{|c|c|c|c|c|c|}
\hline \multicolumn{2}{|c|}{ Coefficient of Determination } & \multirow{2}{*}{ Number of Obs } & \multirow{2}{*}{ Prob $>F$} & \multirow{2}{*}{$\begin{array}{l}\text { The lowest } \\
\text { Prob > F }\end{array}$} & \multirow{2}{*}{ Cons. } \\
\hline R-Squared & 0.9578 & & & & \\
\hline Adjusted R-Squared & 0.9442 & 50 & 0.0120 & 0.0000 & 11.98855 \\
\hline \multirow{3}{*}{\multicolumn{2}{|c|}{ Coefficient }} & lnICSRzakat & \multicolumn{3}{|c|}{-0.3815246} \\
\hline & & ROE & \multicolumn{3}{|c|}{0.6939338} \\
\hline & & ROA & \multicolumn{3}{|c|}{-3.688117} \\
\hline \multirow{3}{*}{\multicolumn{2}{|c|}{ Prob $>t$}} & InICSRzakat & \multicolumn{3}{|l|}{0.581} \\
\hline & & ROE & \multicolumn{3}{|l|}{0.001} \\
\hline & & ROA & \multicolumn{3}{|l|}{0.005} \\
\hline
\end{tabular}

Table 1 showed the result of FEM. Chow test is a testing method to choose between PLS and FEM by observing the value of lowest Prob $>\mathrm{F}$ shown in the table above. The value of the lowest Prob $>\mathrm{F}$ is 
0.0000 , less than 0.05. Thus, the decision based on the testing result is to determine FEM as the best model.

\subsection{LM Test}

LM test is a testing method in panel data regression analysis to choose between Pooled Least Square (PLS) and Random Effect Model (REM) by interpreting REM.

Table 2. Random Effect Model (REM)

\begin{tabular}{|l|l|l|l|l|l|}
\hline R-Squared & \multirow{2}{*}{ Number of Obs } & Prob $>$ Chi $^{2}$ & Cons. \\
\hline Within & Between & Overall & & & \\
\hline 0.2415 & 0.1277 & 0.1305 & 50 & 0.0071 & 16.35649 \\
\hline \multirow{3}{*}{ Coefficient } & lnICSRzakat & -0.7099127 & \\
\cline { 4 - 6 } & ROE & 0.6972719 & \\
\cline { 4 - 6 } & ROA & -3.209455 & \\
\hline \multirow{3}{*}{ Prob $>\mathrm{z}$} & lnICSRzakat & 0.276 & \\
\cline { 3 - 5 } & ROE & 0.001 & \\
\cline { 3 - 5 } & ROA & 0.014 & \\
\hline
\end{tabular}

Table 2 showed the result of REM. LM test is a testing method to choose between PLS and REM by observing the value of Prob $>\mathrm{Chi}^{2}$ shown in the table above. The value of Prob $>\mathrm{Chi}^{2}$ is 0.0071 , less than 0.05 . Hence, the decision based on the testing result is to determine REM as the best model.

\subsection{Hausman Test}

Hausman test is a testing method in panel data regression analysis to choose between Fixed Effect Model (FEM) and Random Effect Model (REM) by interpreting the result shown in the table of the hausman test.

Table 3. Hausman Test Result

\begin{tabular}{|l|l|l|l|l|}
\hline \multirow{2}{*}{} & Coefficient & \multirow{2}{*}{ Difference } & \multirow{2}{*}{ sqrt (diag(V_b-V_B)) } \\
\cline { 2 - 5 } & FEM & REM & & \\
\hline lnICSRzakat & -0.3815246 & -0.7099127 & 0.3283881 & 0.3360341 \\
\hline ROE & 0.6939338 & 0.6972719 & -0.0033381 & 0.0517079 \\
\hline ROA & -3.688117 & -3.209455 & -0.4786621 & 0.273383 \\
\hline Chi $^{2}$ & 8.54 & & \\
\hline Prob $>$ Chi $^{2}$ & 0.0361 & & \\
\hline
\end{tabular}

Hausman test is a testing method to choose between FEM and REM by observing the value of Prob $>\mathrm{Chi}^{2}$ shown in the table above. The value of Prob $>\mathrm{Chi}^{2}$ is 0.0361 , less than 0.05 . Therefore, the decision based on the testing result is to determine FEM as the best model.

\subsection{The Impact of Profitability Ratios and ICSR Disclosure on Islamic Banks' Stock Prices in the Gulf Cooperation Council (GCC) Countries}

Table 4. The Summary of FEM Result

\begin{tabular}{|l|l|}
\hline Section & Value \\
\hline Constanta & 11.98855 \\
\hline Return on Asset (ROA) & -3.68817 \\
\hline Return on Equity (ROE) & 0.6939338 \\
\hline ICSR (zakat spending) & -0.3815246 \\
\hline
\end{tabular}

According to all tests above, the author decided that Fixed Effect Model (FEM) is the best model for this study. It is found that FEM is superior in two testing methods, chow test and hausman test. The data in FEM can be formulated with the following equation model:

$$
\begin{aligned}
S P_{i t}= & 11.98855-3.68817 \text { ROA }_{i t}{ }^{+} \\
& 0.6939338 \text { ROE }_{i t}- \\
& 0.3815246 \text { LnICSRzakat }_{i t}+\varepsilon_{i t}
\end{aligned}
$$

Explanation :

a) Constanta 11.98855 means that if ROA, ROE, and ICSR (zakat) are 0, Islamic banks' stock prices will be at 11.9855 points.

b) The value of -3.68817 is a sign that ROA has a negative impact on observed Islamic banks' stock prices. If ROA decreases by $-3,6887$ point, the stock prices will increase by 1 point.

c) The value of 0.6939338 means that ROE has a positive impact on Islamic banks' stock prices. Increase of ROE by 0.6939338 points will increase the stock prices by 1 point.

d) The value of -0.3815246 means that ICSR (zakat) has a negative impact on Islamic banks' stock prices. Decrease of ICSR (zakat) by -0.3815246 points will increase the stock prices by 1 point. 


\subsection{Hypothesis Test}

a. Coefficient of Determination

The coefficient of determination $\left(\mathrm{R}^{2}\right)$ aims to see the ability of independent variables to explain dependent variables.

Table 5. The Result of Adjusted $\mathbf{R}^{2}$ Provided in FEM

\begin{tabular}{|l|l|}
\hline Section & Value \\
\hline Adjusted $\mathrm{R}^{2}$ & 0.9442 \\
\hline
\end{tabular}

The value of 0.9442 (94.42\%) in Adjusted $\mathrm{R}^{2}$ section provided in FEM result is interpreted as the number of contribution of all the observed independent variables (ROA, ROE, and ICSR in the form of a total of zakat spending) on the dependent variable (Islamic banks' stock prices), while the other value of $0.0558(5.58 \%)$ is explained by other unobserved variables and not provided in this study.

\section{b. Partial Test (t-test)}

The type of this test is used to see the significance level of individual independent variable's impact on dependent variable by reading the result of Prob $>t$. The criteria for this test in this research are explained as follows:

1) If the value of Prob $>t$ less than $\alpha=0.05(<5 \%)$, then the independent variable has a significant influence on the dependent variable.

2) If the value of Prob $>$ t more than $\alpha=0.05(>5 \%)$, then the independent variable has no significant influence on the dependent variable.

Table 6. The Summary of Prob $>t$ in FEM Result

\begin{tabular}{|l|l|l|}
\hline Section & Prob $>$ t & Result \\
\hline ROA & 0.005 & Significant \\
\hline ROE & 0.001 & Significant \\
\hline ICSR (zakat spending) & 0.581 & Insignificant \\
\hline
\end{tabular}

According to the table above, the results are interpreted in the following explanations :

H1 \& H2 = The Profitability Ratios (ROA \& ROE) have a positive significant impact on Islamic banks' stock prices

The value of Prob > t of ROA \& ROE as profitability ratios provided in the table above are $0.005 \& 0.001$, less than $\alpha=0.05(<5 \%)$. It means that both variables have a significant impact on Islamic banks' stock prices. As the results provided aforementioned, ROA has a negative impact (3.68817), and ROE has a positive impact (0.6972719). Therefore, the conclusions are rejecting $\mathrm{H} 1$ and accepting $\mathrm{H} 2$, meaning $\mathrm{H} 1$ has no positive significant and $\mathrm{H} 2$ has a positive significant impact on Islamic banks' stock prices. A negative effect of ROA on the stock prices indicating that the investors have a negative sentiment on the ROA variable of the Islamic banks in the GCC countries. They might not believe in the total of Islamic banks' asset growth as the divider in this profitability ratio. This research supported the previous study conducted by (Al Kalbani et al., 2015) that found there is no positive significant influence of ROA on several observed companies' stock prices listed in MSM 30 Index in Oman during the year of 2005 to 2012.

$\mathrm{H} 2$ is accepted. It means that ROE has a positive significant influence on the Islamic banks' stock prices. This result is in line with a study conducted by (Barakat, 2014) that found there is a positive significant impact of ROE variable on the volatility of companies' stock prices in Saudi Arabia, and (Gharaibeh, 2015) with the result of a positive significant impact of ROE on 48 companies' stock prices listed in Kuwait Stock Exchange (KSE).

\section{H3 = ICSR (zakat) has a positive significant impact on Islamic banks' stock prices}

The value of Prob > $t$ of ICSR (zakat spending disclosure by the Islamic banks) is 0.581 , more than $\alpha$ $=0.05(<5 \%)$. It means that ICSR (zakat) has an insignificant effect on Islamic banks' stock prices. The value of -0.3815246 as the result of FEM shows a negative influence of ICSR (zakat) on Islamic banks' stock prices in the GCC countries. The conclusion in this test is rejecting $\mathrm{H} 3$, meaning ICSR (zakat) has no positive significant effect on Islamic banks' stock prices. ICSR (zakat) is an obligation for companies listed in the GCC countries. Thus, this variable is not considered in making investment decision by investors in that area.

The obligation of zakat spending by existing companies in Saudi Arabia is written on the Royal Court No. 17/2/28/8634 on April 7, 1951. The obligation of paying zakat had to be obeyed by both individuals and companies in the country (Labib, 2017). This regulation is different from other Muslimmajority countries, like Malaysia and Indonesia. Malaysia implemented paying zakat as an instrument to deduct tax amount, while Indonesia applied zakat paying as an instrument to deduct earning with income tax (Ridwan, 2014). Both countries applied the regulation of collaborating zakat and tax, thus paying zakat is a choice for companies. Zakat is an interesting 


\section{Jurnal Ilmiah Ekonomi Islam, 6(03), 2020, 541}

variable for investment decision making for Islamicbased investors in both countries, but it does not apply with companies in the middle-east countries, particularly in the GCC countries.

This result confirmed a previous research conducted by (Derakhshanzade \& Rezaie, 2015) which found there is no significant impact of CSR variable on the falling of stock prices in several companies listed in Tehran Stock Exchange in Iran in the year of 2013.

\section{c. Simultan Test (F-test)}

The result of simultan test can be seen in the following table:

Table 7. Prob $>$ F in FEM Result

\begin{tabular}{|l|l|l|}
\hline Section & Value & Result \\
\hline Prob $>$ F & 0.012 & Significant \\
\hline
\end{tabular}

The value of Prob > F is 0.012 , less than $\alpha=0.05$ $(<5 \%)$ which means all the independent variables (ROA, ROE, and ICSR in the form of zakat spending disclosure) in this research simultaneously have a significant impact on Islamic banks' stock prices.

\section{CONCLUSION}

ROA variable has a negative significant impact on Islamic banks' stock prices in the GCC countries. This conclusion indicated a negative sentiment for the observed Islamic banks from investors' perspective inside the market. It is also a sign that the growth of Islamic banks' asset written on the financial report in the GCC countries is questionable among the Islamic capital market's investors. The reported net income is not doubted like the growth of Islamic banks' asset. ROE which involving net income and total of Islamic banks' equity confirmed this conclusion with its positive significant impact on the same dependent variables. If the problem is in reported net income, a negative significant should not be only in ROA variable, but also in ROE profitability ratio. The authors suggested to all Islamic banks across the world to gain investors' confidence in their financial condition before entering the Islamic capital market. To make some significant strategies, like education and socialization regarding the condition, sustainability, and opportunity of Islamic banks in the future among investors can be one solution to gain it. Investing is a serious act for most investors in both general and Islamic capital market. A negative sentiment on specific financial condition will ruin their willingness to do investment.
ICSR (zakat spending) has a negative insignificant impact on Islamic banks' stock prices. This conclusion is an indicator that paying zakat is not an exciting variable in investment consideration, particularly in the GCC countries. Zakat is an obligation for both individuals and companies in that area. Thus, investors do not make total of zakat payment as a consideration in the investment decisionmaking process.

\section{REFERENCES}

Al Kalbani, Zaynab, Vinay R. Gupta, D. Mamtha, and Asma Al-Hanai. (2015). Impact of Financial Crisis on Stock Prices of Companies in Oman. International Journal of Business Management \& Research (IJBMR). 5(2).

Al-Nimer, Munther, Lina Warrad, and Rania Al Omari. (2013). The Effect of Return on Assets and Earnings Per Share and Dividends Per Share on Stock Prices of Publicly Listed Banks in Jordan. International Journal of Marketing, Financial Services, and Management Research. 2(3).

Barakat, Abdallah. (2014). The Impact of Financial Structure, Financial Leverage, and Profitability on Industrial Companies Shares Value (Applied Study on a Sample of Saudi Industrial Companies). Research Journal of Finance and Accounting. 5(1).

Derakhshanzade, Amin and Rezaie, Hamideh. (2015). Explanation of the Relationship between Corporate Social Responsibility and Falling Risk of Stock Prices in Companies of the Tehran Stock Exchange. International Research Journal of Management and Sciences. 3(12).

Dixon, Rob, Elena Platonova, Mehmet Asutay, and Sabri Mohammad. (2016). The Impact of Corporate Social Responsibility Disclosure on Financial Performance: Evidence from the GCC Islamic Banking Sector. Journal of Business Ethics.

Djarwanto. (1997). Pokok-pokok Analisa Laporan Keuangan. Yogyakarta: BPFE.

Gharaibeh, Ahmad Mohammad Obeid. (2015). The Determinants of Common Share Prices: New Empirical Evidence From Kuwait. EPRA International Journal of Economic and Business Review. 3(11).

Hadi, Nur. (2011). Corporate Social Responsibility. Edisi Pertama. Yogyakarta: Graha Ilmu. 
Jurnal Ilmiah Ekonomi Islam, 6(03), 2020, 542

Hartono, J. (2008) Teori Portofolio dan Analisis Investasi. Edisi 5. Yogyakarta: BPFE.

Jogiyanto, H.M. (2000). Teori Portofolio dan Analisis Investasi. Yogyakarta: BPFE.

Mahmudi. (2009). Sistem Akuntansi Organisasi Pengelola Zakat. Yogyakarta: P3EI.

Mughni Labib. (n.d.). Keberhasilan Pengelolaan Zakat di Arab Saudi. Retrieved April 20, 2017, from

www.darussaadah.or.id/kajian/18/Keberhasilan Pengelolaan_Zakat_di_Arab_Saudi.html.

Pinches, George E. (1996), Essential of Financial Management. New York: Harver Collins College Publishers.

Reskino. (2016). Zakat and Islamic Corporate Social Responsibility: Do These Effect the Performance of Sharia Banks?. Shirkah Journal of Economics and Business. 1(2).

Ridwan, Murtadho. (2014). Zakat VS Pajak: Studi Perbandingan di Beberapa Negara Muslim. ZISWAF. 1(1).
Sikimic, S. (n.d.). Profile, What Is The GCC? Retrieved February 20, 2017, from www.middleeasteye.net.

Suhardjono, Mudrajad Kuncoro. (2002). Manajemen Perbankan Teori dan Aplikasi. Y Yogyakarta: BPFE.

Suharli, M. (2008). Studi Empiris Terhadap Dua Faktor Yang Mempengaruhi Return Saham Pada Industri Food \& Beverages di Bursa Efek Jakarta. Jurnal Akuntansi dan Keuangan. 7(2).

Tandelilin, Eduardus. (2001). Analisis Investasi dan Manajemen Portofolio. Yogyakarta: BPFE.

Widiatmojo. (2001). Cara Sehat Investasi Manajemen Portofolio. Yogyakarta: BPFE.

Yusuf, Muhammad Yasir and Bahari, Zakaria bin. (2015). Corporate Social Responsibility in Islamic Banking: Towards Poverty Alleviation. Ethics, Governance, and Regulation in Islamic Finance. 